\title{
Karakter Birokrasi Pemerintahan Dalam Pelayanan Perizinan Mendirikan Bangunan Di Dinas Penanaman Modal Pelayanan Terpadu Satu Pintu Kabupaten Karawang
}

\author{
Rachmat Ramdani \\ Program Studi Ilmu Pemerintahan \\ Fakultas Ilmu Sosial dan Ilmu Politik \\ Universitas Singaperbangsa Karawang \\ rachmat.ramdani@fisip.unsika.ac.id
}

\begin{abstract}
This study aims to analyze the character of government bureaucracy in the IMB licensing services in DPMPTSP Karawang Regency. This writing is based on the government bureaucracy in the Karawang Regency DPMPTSP Office in providing licensing services to build a building that has not gone well. The question will be discussed how the characteristics of government bureaucracy in the IMB licensing services in DPMTPSP Karawang Regency. This writing uses a descriptive method with a qualitative approach. The purpose of this paper is to determine the character of the bureaucracy in the IMB licensing services in DPMPTSP, Karawang Regency. Data collection techniques are carried out through literature study and field studies in the form of observation as well as interviews and documentation. The results of the discussion showed that the character of the bureaucracy in the IMB licensing services in DPMPTPSP Karawang Regency viewed from several aspects. First, the existence of a long hierarchy in providing IMB licensing services at DPMPTSP Karawang regency has the same meaning as stated by Max Weber in his ideal type of bureaucracy. Second, the formalization of rules and procedures in the bureaucratic licensing services of the IMB do DPMPTSP Karawang regency as reflecting the Weberian ideal type bureaucracy which states that formalization is needed as a basis for decision making of a bureaucratic official in providing services so that the services provided can be fast and fair. Third, debureaucratization cuts convoluted bureaucratic structures and procedures for the efficient and effective DPMPTSP of Karawang Regency to conduct bureaucratization because licensing services are overdone and beyond the point of optimization.
\end{abstract}

\section{Keywords: Bureaucratic Characteristics, IMB Licensing Services, DPMPTPSP}

Abstrak
Penelitian ini bertujuan untuk menganalisis karakter birokrasi pemerintahan dalam
pelayanan perizinan IMB di DPMPTSP Kabupaten Karawang. Penulisan ini di
latarbelakangi birokrasi pemerintahan di Kantor DPMPTSP Kabupaten Karawang dalam
memberikan pelayanan perizinan mendirikan bangunan belum berjalan dengan baik.
Pertanyaan yang akan dibahas bagaimana karakteristik birokrasi pemerintahan dalam
pelayanan perizinan IMB di DPMTPSP Kabupaten Karawang. Penulisan ini menggunakan
metode deskriptif dengan pendekatan kualitatif. Tujuan penulisan ini untuk mengetahui
karakter birokrasi dalam pelayanan perizinan IMB di DPMPTSP Kabupaten Karawang.
Teknik pengumpulan data yang dilakukan melalui studi pustaka dan studi lapangan
berupa observasi serta wawancara dan dokumentasi. Hasil pembahasan menunjukan
bahwa karakter birokrasi dalam pelayanan perizinan IMB di DPMPTPSP Kabupaten
Karawang dilihat dari beberapa aspek. Pertama, keberadaan hirarkhi yang panjang
dalam memberikan pelayanan perizinan IMB di DPMPTSP Kabupaten Karawang terdapat
makna yang sama seperti yang di kemukakan oleh Max Weber dalam type birokrasi
idealnya. Kedua, formalisasi aturan dan prosedur dalam birokrasi pelayanan perizinan
IMB do DPMPTSP Kabupaten Karawang sebagaimana mencerminkan birokrasi type ideal


Weberian yang menyatakan bahwa formalisasi diperlukan sebagai dasar pengambilan keputusan seorang pejabat birokrasi dalam memberikan pelayanan agar pelayanan yang diberikan dapat cepat dan adil. Ketiga, debirokratisasi memangkas struktur dan prosedur birokrasi yang berbelit-belit untuk efisien dan efektivitas DPMPTSP Kabupaten Karawang melakukan debirokratisasi karena pelayanan perizinan sudah berlebihan dan melewati titik optimalisasi.

\section{Kata kunci: Karakter Birokrasi, Pelayanan Perizinan IMB, DPMPTPSP}

\section{Pendahuluan}

Dalam perspektif negara moderen, tugas birokrasi pemerintah dan sekaligus menjadi hak bagi warga negara yaitu menyelenggarakan pelayanan publik. Kehadiran birokrasi pemerintah dengan fungsi pelayanan bertujuan untuk menciptakan pelayanan yang adil bagi warga negara. Maka dari itu kehadiran birokrasi pemerintah penting dan sangat dibutuhkan karena birokrasi merupakan institusi formal yang mendapatkan legitimasi politik masyarakat untuk menjalankan fungsi pelayanan, pemberdayaan dan pembangunan.

Pemerintah pusat melalui Kementerian Pendayagunaan Aparatur Negara berinisiatif mengeluarkan regulasi dengan menerbitkan keputusan Menteri Pendayagunaan Aparatur Negara (Menpan) Nomor 63/Kep.PAN/7/2003 Tentang Pelayanan Publik yang menjelaskan bahwa kegiatan pelayanan yang dilaksanakan oleh penyelenggaran pelayanan publik sebagai upaya pemenuhan kebutuhan warga negara. Dalam peraturan tersebut menjelaskan terdapat beberapa jenis pelayanan publik yang diberikan oleh pemerintah kepada masyarakat dan diantaranya adalah pelayanan perizinan.

Pelayanan perizinan menurut Ridwan (2009) merupakan hak yang sangat penting bagi masyarakat karena perizinan merupakan instrumen yuridis yang digunakan oleh pemerintah yang berfungsi sebagai ujung tombak pengarah, rekayasa dan perancang untuk mewujudkan masyarakat adil dan makmur. Pelayanan perizinan bagian penting yang diselenggarakan oleh pemerintah sebagai fungsi pelayanan kepada masyarakat. Berkaitan dengan pelayanan perizinan tersebut, pemerintahan pusat mengeluarkan peraturan Menteri Dalam Negeri Nomor 24 Tahun 2006 Tentang Pedoman Penyelenggaraan Pelayanan Terpadu Satu Pintu kebijakan ini merupakan langkah awal pemerintah pusat dalam melakukan reformasi birokrasi pemerintahan yang bertujuan untuk meningkatkan kualitas pelayanan publik.

Permendagri Nomor 24 Tahun 2006 tersebut merupakan kebijakan dari pemerintah pusat yang akan dilaksanakan oleh pemerintah daerah dalam rangka meningkatkan reformasi birokrasi dalam pelayanan publik di daerah. Dengan adanya pelayanan terpadu satu pintu tersebut pemerintah daerah dapat memberikan pelayanan yang efektif dan efisien. Namun, dalam realitasnya pelayanan perizinan satu pintu masih dirasakan belum memuaskan masyarakat. Berkaitan dengan hal tersebut mengkonfirmasikan masalah pelayanan perizinan di daerah terletak pada reformasi 
birokrasi pemerintahan yang belum memuaskan harapan masyarakat. Dalam hal ini Pemerintah Daerah Kabupaten Karawang telah mengambil langkah kebijakan untuk menerapkan pelayanan perizinan terpadu satu pintu sebagai upaya reformasi birokrasi di daerah. Pelayanan perizinan yang diselenggarakan oleh Dinas Penanaman Modal Dan Pelayanan Terpadu Satu Pintu (DPMPTSP) Kabupaten Karawang. Pembentukan kelembagaan dari DPMPTSP dalam menyelenggarakan pelayanan perizinan dapat mendorong kepercayaan masyarakat terhadap pemerintah daerah selain itu juga dapat memberikan dampak positif terhadap peningkatan pendapatan asli daerah Kabupaten Karawang.

Sesuai dengan apa yang diungkapkan oleh Ryas Rasyid (1998) menyatakan bahwa pemerintah pada hakekatnya adalah pelayanan pada masyarakat, pemerintah tidak diadakan untuk dilayani tetapi untuk melayani masyarakat serta menciptakan kondisi yang memungkinkan untuk setiap anggota masyarakat mengembangkan kemampuan dan kreatifitasnya untuk mencapai tujuan bersama. Pelayanan perizinan yang diselenggarakan oleh DPMPTSP Kabupaten Karawang sebagai upaya reformasi birokrasi pelayanan perizinan. Namun, dalam pelaksanaan pelayanan perizinan izin mendirikan bangunan masih menunjukan fenomena permasalahan. Permasalahan mengenai kemudahan dan kecepatan pelayanan perizinan belum berjalan dengan baik diperkuat dengan data hasil rekapitulasi Indeks Kepuasaan Masyarakat yang diselenggarakan oleh DPMPTSP Kabupaten Karawang terhadap pelayanan perizinan.

Grafik. 1.1

Nilai rata-rata per unsur IKM 2016

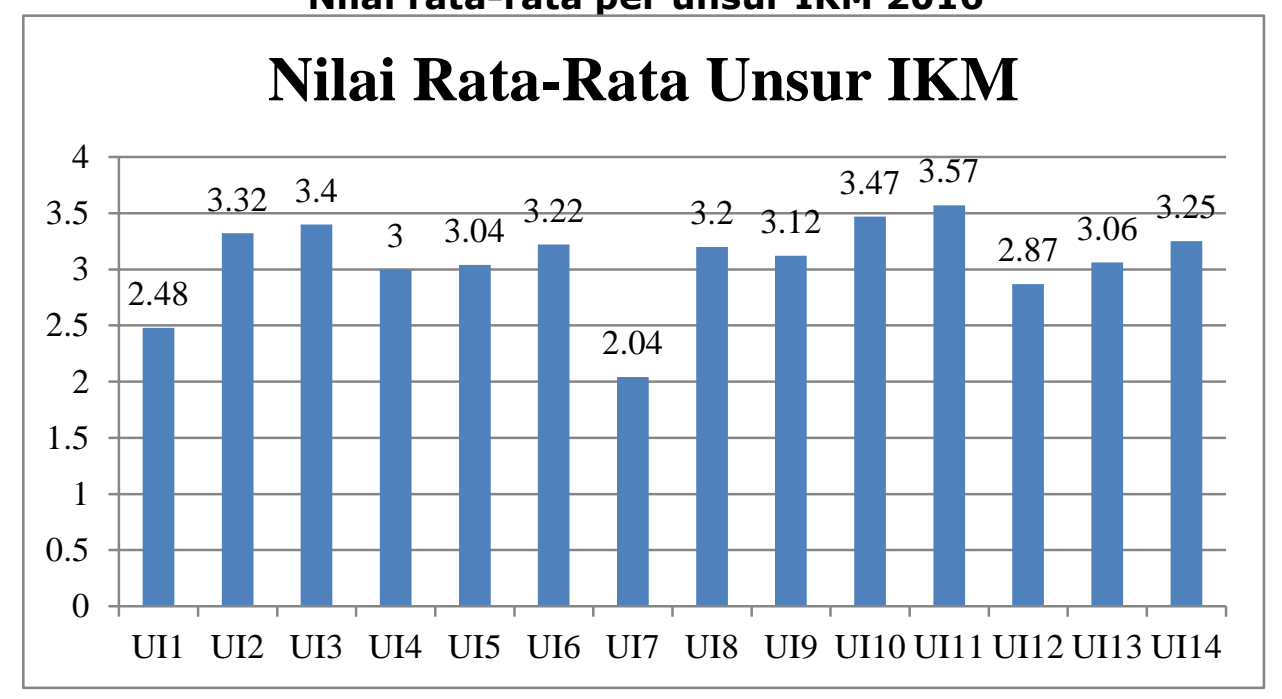

Sumber: Dinas Penanaman Modal Pelayanan Terpadu Satu Pintu

Berdasarkan grafik diatas, menunjukan hasil dari deskripsi responden survai indeks kepuasaan masyarakat di DPMPTSP Kabupaten Karawang dengan sampel 185 responden pelanggan yang terdiri dari karakteristik responden berdasarkan kelompok umur, 
karakteristik jenis kelamin, karakteristik pendidikan dan karakteristik pekerjaan. Berdasarkan Grafik tersebut di atas, dapat dijelaskan bahwa: Nilai rata-rata (NRR) perunsur IKM yang paling rendah adalah unsur IKM No. 7 tentang Kecepatan Pelayanan dengan $N R R=2,04$ sebanyak 54 Orang (64\%) masyarakat mengatakan kecepatan pelayanan yang diberikan di DPMPTSP Kabupaten Karawang kurang cepat. No. 1 tentang prosedur pelayanan dengan $\mathrm{NRR}=2,48$ pada unsur ini 37 Orang $(44 \%)$ responden mengatakan prosedur pelayanan yang dilakukan di DPMPTSP Kabupaten Karawang kurang mudah. Sedangkan yang paling tinggi adalah NRR unsur IKM No. 11 tentang Kejelasan dan Kepastian Biaya Pelayanan dengan NRR= 3,57 dari 51 Orang (61\%) mengatakan biayanya sangatlah sesuai.

Fenomena pelayanan perizinan diatas menunjukan belum termanisfestasikan penyelenggaran pelayanan perizinan yang cepat, responsif dan murah biaya, hal ini mengindentifikasi birorkrasi pemerintahan belum berjalan dengan baik dalam penyelenggaran pelayanan perizinan mendirikan bangunan yang memuaskan masyarakat sebagai pengguna jasa. Fenomena tersebut menimbulkan ketertarikan peneliti untuk mengadakan penelitian lebih dalam tentang birokrasi pemerintahan dalam pelayanan perizinan mendirikan bangunan, dimana bagi peneliti permasalahan birokrasi pemerintahan dalam pelayanan ini menarik mengingat belum berjalan dengan baik fungsi pemerintah dalam pelayanan publik yang baik dan berkualitas banyak dipengaruhi oleh birokrasi pemerintahan itu sendiri.

\section{Tinjauan Pustaka}

Faktor dan aktor utama yang turut berperan dalam mewujudkan pemerintahan yang bersih (clean government) dan kepemerintahan yang baik (good governance) yaitu birokrasi. Posisi dan peran birokrasi pemerintah yang demikian penting dalam pengelolaan kebijakan dan pelayanan publik bahwa birokrasi sangat menentukan efisiensi dan efektif pelayanan kepada masyarakat. Dalam berbagai kegiatan pelayanan yang diselenggarakan oleh pemerintah tidak bisa dilepaskan dari keberadaan birokrasi pemerintah, karena birokrasi pemerintah masih sangat dominan dalam pelaksanaan pemerintahan. Birokrasi Pemerintahan masih dominan yang menguasai pengetahuan dan informasi karena memiliki dukungan sumber daya yang sangat besar dan tidak dimiliki oleh pihak lain. Dengan posisi dan kemampuan yang besar tersebut birokrasi pemerintahan memiliki kewenangan untuk membuat kebijakan dan menjalankan kebijakan secara teknis.

JB Kristiadi (1991) mengatakan bahwa birokrasi adalah struktur organisasi di sektor pemerintahan yang memiliki ruang lingkup tugas yang sangat luas serta memerlukan organisasi besar dengan sumber daya manusia yang besar pula jumlahnya. 
260 | Rachmat Ramdani. Karakter Birokrasi Pemerintahan...

Birokrasi pemerintahan yang dimaksud yaitu birokrasi sebagai penyelenggaran pemerintahan yang mengelola berbagai sumber daya. Berdasarkan terminologi ilmu politik, menurut Eep Saefulloh Fatah (1998) dikenal empat model birokrasi yang umumnya ditemui dalam praktek pembangunan di dunia ketiga, yaitu: Weberian, Parkinsonan, Jacksonian, dan Orwellian. Namun dari keempat teori tersebut yang akan di jelaskan dalam penulisan ini adalah model birokrasi Weberian. Weber (1947) dikenal dengan konsepnya mengenai tipe ideal bagi sebuah otoritas legal rasional, otoritas legal rasional disini adalah birokrasi kriteria-kriteria tipe ideal birokrasi yaitu;

Pertama, "A continous organization of official functions bound by rules". [Tugastugas pejabat diorganisir atas dasar aturan yang Berkesinambungan]. Kedua, "A specific sphere of competence". [Tugas-tugas tersebut dibagi atas bidang-bidang yang berbeda sesuai dengan fungsinya di bidang yang kompeten, yang masing-masing di lengkapi dengan syarat otoritas dan sanksi-sanksi. Ketiga, "The organization of officers follows the principle of hierarchy". [Jabatan-jabatan tersusun secara hirarkis, yang disertai dengan rincian hak-hak kontrol dan pengaduan]. Keempat, "The rules which regulate the conduct of an office may be technicalrules or norms". [Aturan-aturan yang sesuai dengan pekerjaan diarahkan baik secara teknis sesuai dengan aturan dan norma]. Kelima,"The members of the administratitive staff should be completelyseparated from ownership of the means of production oradministration". [Anggota sebagai sumber daya organisasi berbeda atau terpisah dengan anggota sebagai individu pribadi]. Keenam, "There is also a complete absence of appropriation of his official position by the incumbent". [Pemegang jabatan tidak sama dengan jabatannya]. Ketujuh, "Administrative act's, decision, and rules are formulated andrecorded in writing". [Administrasi di dasarkan pada dokumen-dokumen tertulis dan hal ini cenderung menjadikan kantor (biro) sebagai pusat organisasi modern]. Kedelapan, "Legal authority can be exercised in a wide variety of different form swhich will be distinguis hed and discussed later". [Sistem otoritas legal dapat mengambil banyak bentuk, tetapi dilihat padabentuk aslinya, sistem tersebut tetap berada dalam suatu staf administrasi birokratik].

Dari poin kedelapan diatas menjadi dasar birorkasi ideal weberian yang harus dimiliki oleh para birokrat agar tugas-tugas yang besar dapat dilaksanakan secara efektif dan efisien sehingga tujuan organisasi dapat tercapai sesuai yang direncanakan. Jika kedelapan poin diatas diaplikasikan ke dalam birokrasi maka birokrasi tersebut dapat dikatakan legal-rasional. Lebih spesifik tipe karakter ideal birorkrasi Weberian menjelaskan kriteria tentang tipe birokrasi idela sebagai berikut: Pertama, Pembagian kerja/spesialisasi kerja (division of labor) menurut Weber dalam menjalankan berbagai tugasnya, birokrasi membagi kegiatan-kegiatan pemerintah menjadi bagian-bagian yang 
masing-masing terpisah dan memiliki fungsi yang khas. Kedua, Prinsip hierarki wewenang (the principle of hierarchi) menurut Weber ciri khas birokrasi adanya wewenang yang disusun secara hierarkhis atau berjenjang. Hierarkhi membantu pimpinan birokrasi untuk melakukan supervisi dan kontrol terhadap para anggotanya juga memiliki potensi menghasilkan serangkaian masalah birokrasi.Ketiga, Formalisasi aturan (system of rules) Weber sistem aturan juga menjamin koordinasi berbagai tugas yang berbeda dan menjamin keseragaman pelaksanaan berbagai kegiatan. Formalisasi aturan dan prosedur sebagai dasar bagi pengambilan keputusan pimpinan birokrasi dalam memberikan pelayanan agar pelayanan yang diberikan cepat dan adil. Keempat, Hubungan impersonal (formalistic impersonality), prinsip impersonalitas yang di kembangkan oleh Weber untuk mendorong agar para birokrasi dapat bertindak adil dan bersikap nonpartisan dalam melayani masyarakat.

Para ahli lain mengemukakan pendapat bahwa struktur dan manajemen model pemerintahan tradisional ala Weber sudah usang dan membutuhkan perubahan yang dratis. Sehingga memunculkan sebuah gerakan reformasi di sektor publik yaitu dengan adanya konsep NPM. Ditinjau dari perspektif historis menurut istilah NPM pada awalnya di kenalkan di Eropa tahun 1980-an dan 1990-an sebagai reaksi terhadap tidak memadai administrasi publik tradisional. Selain itu, dalam kondisi masyarakat yang semakin kritis di atas birokrasi pemerintah dituntut harus dapat mengubah posisi dan peran (revitalisasi) dalam memberikan pelayanan publik. Dari yang suka mengatur dan memerintah berubah menjadi suka melayanai, dari yang suka menggunakan pendekatan kekuasaan, berubah menjadi suka menolong menuju ke arah yang fleksibel kolaboratis dan dialogis dan dari cara-cara yang sloganis menuju cara-cara kerja yang realistik pragmatis.

Konsep NPM yang mampu menjawab adanya tuntuan masyarakat yang semakin besar agar sektor publik dapat menghasilkan kualitas pelayanan publik lebih baik atau minimal sama dengan yang dihasilkan oleh pihak swasta. Para ahli yang menolak konsep birokrasi weberian menganjurkan pemerintah untuk melakukan debirokratisasi, deregulasi dan privatisasi dalam kegiatan pelayanan publik. Seperti yang diungkapkan menurut Caiden (1991) Strategi reformasi birokrasi yaitu: Pertama, Privatisasi dan koproduksi, menyerahkan kewenangan penyediaan barang dan jasa publik kepada swasta.Kedua, Debirokratisasi, memangkas struktur dan prosedur birokrasi yang berbelit-belit untuk efisiensi dan efektivitas kepemerintahan. Ketiga, Reorganisasi, menata ulang organisasi publik sesuai dengan tugas pokok dan fungsinya (tupoksi) agar lebih fleksibel. Keempat, Manajemen publik yang efektif, memperbaiki proses manajerial pada organisasi publik agar lebih efektif dalam menjalankan fungsinya. Kelima, Value for money, menghapus kegiatan-kegiatan yang tidak penting yang dapat menghabiskan anggaran. 
262 | Rachmat Ramdani. Karakter Birokrasi Pemerintahan...

Strategi reformasi birokrasi yang di kemukakan oleh Caiden seolah menjadi perbaikan dari problema yang sekarang dihadapi oleh birokrasi dalam memperbaiki kinerjanya. Dengan melakukan strategi reformasi birokrasi tersebut maka pemerintah di percaya akan dapat memperbaiki kinerja birokrasinya. Hal tersebut di karena kan terdapat wacana untuk melakukan debirokratisasi, deregulasi dan privatisasi sangat menonjol. Munculnya gerakan NPM dan reinventing goverment di negara-negara maju menunjukan besarnya keinginan untuk melakukan debirokratisasi dalam penyelenggaran pemerintah dan pelayanan publik.

Selanjutnya, periode ketiga dalam perkembangan yaitu periode NPS. Berbeda dengan paradigma OPA dan NPM, paradigma NPS adalah paradigma yang menekankan berbagai elemen. Walaupun demikian NPS mempunyai normatif model yang dapat dibedakan dengan konsep-konsep lainnya. Menurut Thoha (2008) menyatakan bahwa ide dasar dari NPS dibangun dari (1) teori democratic citizenship; (2) model komunitas dan civil society; (3) organisasi humanism; (4) postmodern ilmu administrasi publik. Karakteristik NPS ini mengedepankan posisi masyarakat sebagai warga negara dalam konteks governance. Dalam perspektif ini pelayanan kepada masyarakat merupakan tugas utama bagi birokrasi sekaligus sebagai fasilitator bagi perumusan kepentingan publik dan partisipasi masyarakat dalam pemerintahan. Perspektif ini juga mengakui bahkan menuntut adanya partisipasi masyarakat dalam berbagai jenjang pemerintahan. Dalam penyelenggaran pemerintahan, partisipasi masyarakat merupakan unsur penting dalam perspektif NPS.

Prinsip-prinsip atau asumsi dasar dari NPS Robert Denhardt \& Janet Denhardt (2003) sebagai berikut; Pertama, Melayani warga Negara, bukan pelanggan Kepentingan publik adalah hasil suatu dialog tentang nilai-nilai bersama ketimbang kumpulan diri individual. Oleh karena itu, pelayanan public tidak hanya bertanggung jawab pada tuntutan para pelanggan, tetapi lebih tepatnya berfokus pada pembangunan hubungan kepercayaan dan kolaborasi dengan warga Negara. Kedua, Menegaskan kepentingan publik Adminstrasi publik harus memberikan sumbangan untuk membangun suatu gagasan kolektif kepentingan public yang dianut bersama. tujuannya adalah bukan untuk menemukan solusi-solusi yang tepatnya, adalah menciptakan kepentingankepentingan bersama dan tanggung jawab bersama.

Ketiga, Menghargai warga Negara melebihi kewirausahaan kepentingan publik lebih baik dimajukan oleh pelayan publik dan warga Negara yang bertekad memberikan sumbangan bermakna kepada masyarakat ketimbang oleh manajer usahawan yang bertindak seakan-akan uang publik itu adalah milik mereka sendiri. Keempat, Berpikir secara strategis, bertindak secara demokratis kebijakan dan program memenuhi kebutuhan publik dapat dicapai secara paling efektif dan paling bertanggung jawab melalui usaha kolektif dan proses kolaboratif. Kelima, Mengakui bahwa akuntabilitas 
tidak sederhana pelayanan public harus lebih memperhatikan ketimbang pasar, masyarakat juga mematuhi undang-undang dan hukum konstitusional, nilai komunitas, norma politik, standar professional dan kepentingan warga Negara.

Keenam, Melayani bukan menyetir semakin penting bagi para pelayanan public untuk menggunakan kepemimpinan berbasis nilai-nilai yang dianut bersama dalam membantu warga Negara mengutarakan secara jelas dan memenuhi kepentingan bersama mereka ketimbang berusaha mengendalikan atau menyetir masyarakat dalam arah-arah baru. Ketujuh, Menghargai manusia, bukan sekedar produktivitas organisasi publik dan jaringan tempat mereka berpartisipasi lebih mungkin berhasil dalam jangka panjang jika mereka bekerja melalui proses-proses kolaborasi dan kepemimpinan bersana yang didasarkan pada penghargaan terhadap semua orang.

Hal yang penting dari paradigma NPS bahwa birokrasi harus di bangun agar dapat memberi perhatian kepada pelayanan masyarakat sebagai warga negara bukan sebagai pelanggan, mengutamakan kepentingan umum, mengikutsertakan warga masyarakat, berpikir strategis dan bertindak demokratis, memperhatikan norma, nilai dan standar yang ada dan menghargai masyarakat. Perbaikan kinerja birokrasi pelayanan publik diharapkan akan memperbaiki kembali citra pemerintah di mata masyarakat karena dengan kualitas pelayanan publik yang semakin baik, kepuasan dan kepercayaan masyarakat bisa di bangun kembali.

\section{Metode Penelitian}

Penulisan ini bertujuan untuk menganalisis karakter birokrasi pemerintahan dalam pelayanan perizinan mendirikan bangunan di DPMPTSP Kabupaten Karawang dengan menggunakan pendekatan kualitatif. Pengumpulan data dilakukan melalui wawancara mendalam dengan para informan yang terlibat dalam pelayanan perizinan mendirikan bangunan. Selain itu, data sekunder yang diperoleh melalui peraturan-peraturan yang berkaitan dengan pelayanan perizinan mendirikan bangunan di DPMPTSP Kabupaten Karawang. Pengelolaan data dilakukan dengan mengikuti tahapan dari konsep yang dikemukakan oleh Miles dan Huberman (1992) yakni pengumpulan data, reduksi data dan penyajian data. Hasil analisa data yang dikumpulkan kemudian dianalisis berdasarkan pada konsep birokrasi dilihat dari beberapa aspek. Prinsip Hirarkhi, Formalisasi Prosedur Aturan, Debirokratisasi.

\section{Pembahasan}

\section{a. Birokrasi Dalam Pelayanan Perizinan IMB Di DPMPTSP Kabupaten Karawang}

Menghidupkan perekonomian daerah dengan cara mendorong investasi. Investai tidak dapat dilakukan tanpa melibatkan sektor swasta dan masyarakat luas mengingat keterbatasan pemerintah daerah. Hal yang menjadi kendala bagi minat berinvestasi yaitu proses pelayanan perizinan yang terkesan berbelit dan tidak transparan. Upaya 
264 | Rachmat Ramdani. Karakter Birokrasi Pemerintahan...

untuk meningkatkan arus masuk investasi PMA dan PMDN ke daerah, penerapan one stop service menjadi sangat strategis dan mendesak. Dalam menghadapi era globalisasi yang penuh tantangan dan peluang, birokrasi pemerintah sudah seyogyanya memberikan pelayanan kepada publik yang sebaik-baiknya yang berorientasi kemudahan pelayanan yang terakses dan tersedia bagi masyarakat.

Reformasi pelayanan publik bidang perizinan dengan terbitnya Peraturan Menteri Dalam Negeri Nomor 24 Tahun 2006 tentang Pedoman Penyelenggaraan Pelayanan Terpadu Satu Pintu. Ide dasar dari kebijakan ini adalah mengintegrasikan seluruh proses perizinan ke dalam suatu sistem Pelayanan Perizinan Terpadu Satu Pintu (PTSP) atau One Stop Service. Kebijakan pemerintah tersebut perlu mendapatkan dukungan dari Pemerintah Kabupaten/Kota sebagai penyelenggara layanan langsung kepada masyarakat. Pemerintah Daerah Kabupaten Karawang merespon positif kebijakan tersebut dengan mengimplementasikan kebijakan sistem Pelayanan Perizinan Terpadu Satu Pintu (PTSP) atau One Stop Service.

Adapun langkah pertama yang dilakukan adalah restrukturisasi organisasi dan perangkat daerah berdasarkan Peraturan Daerah Nomor 9 Tahun 2011 Tentang Sekretaris Daerah, Sektertaris DPRD, Dinas Daerah, Lembaga Teknis Daerah, Kecamatan dan Kelurahan Kabupaten Karawang maka dibentuk Badan Penanaman Modal dan Pelayanan Terpadu Kabupaten Karawang dengan tugas pokok, fungsi dan tata kerja yang dijabarkan dalam Peraturan Bupati Karawang Nomor 24 Tahun 2012 yaitu sebagai lembaga teknis daerah yang mempunyai tugas pokok melaksanakan sebagian kewenangan daerah di bidang penanaman modal dan pelayanan perizinan serta tugas pembantuan yang ditugaskan kepada pemerintah daerah.

Perubahan dinas penanaman modal pelayanan terpadu satu pintu berdasarkan pada keputusan Peraturan Daerah Kabupaten Karawang Nomor 68 Tahun 2016 Tentang Penyelenggaraan Pelayanan Terpadu Satu Pintu. Dalam perjalannya BPMPT berubah menjadi Dinas Penanaman Modal Pelayanan Terpadu Satu Pintu Kabupaten Karawang yang ditetapkan melalui Peraturan Daerah Kabupaten Karawang Nomor 02 Tahun 2015 Tentang Penanaman Modal, dan Peraturan Daerah Kabupaten Karawang Nomor 68 Tahun 2016 Tentang Penyelenggaraan Pelayanan Terpadu Satu Pintu serta Peraturan Bupati Karawang Nomor 68 Tahun 2015 Tentang Perubahan Ketiga Atas Peraturan Bupati Nomor 40 Tahun 2014 Tentang Pelimpahan Sebagian Urusan Pemerintah Dari Bupati Karawang Kepada Perangkat Daerah Kabupaten Karawang.

Pelayanan perizinan merupakan suatu masalah yang sangat kompleks, untuk mendirikan sebuah bangunan masyarakat harus memiliki surat izin mendirikan bangunan, karena tanpa memiliki izin maka bangunan akan di katakan illegal oleh pemerintah yang sewaktu-waktu dapat dirobohkan oleh pemerintah. Tingginya tingkat pembangunan di Kabupaten Karawang dapat di lihat secara kasat mata, tidaklah 
mengherankan Kabupaten Karawang membuat ketertarikan investor untuk menanamkan modalnya karena banyaknya urbanisasi masyarakat pendatang ke Kabupaten Karawang. Tingginya pembangunan di Kabupaten Karawang dapat dilihat dari banyak izin mendirikan bangunan yang dikeluarkan oleh pemerintah kabupaten karawang dalam hal ini DPMPTSP.

Banyaknya izin mendirikan bangunan yang di keluarkan pemerintah daerah Kabupaten Karawang dari tahun ketahun menunjukkan tingginya kesadaran masyarakat Kabupaten Karawang untuk mentaati aturan yang telah ditetapkan oleh pemerintah. Hal inilah yang memberikan sumbangsi terhadap Pendapatan Asli Daerah (PAD) Berikut realisasi Retribusi Perizinan Tertentu di Kabupate Karawang:

Tabel 1.1

Realisasi Retribusi Perizinan Tertentu di Kabupaten Karawang

\begin{tabular}{|c|c|c|c|c|c|}
\hline THN & Murni & ABT & Total & Realisasi & $\%$ \\
\hline 2012 & 15.764 .186 .256 & & 15.764 .186 .256 & 18.291 .765 .798 & $116,03 \%$ \\
\hline 2013 & 27.674 .000 .000 & 5.400 .000 .000 & 33.074 .000 .000 & $35.151 .917 .0 \quad 00$ & $106,28 \%$ \\
\hline 2014 & 58.682 .755 .000 & 1.152 .750 .000 & 59.835 .505 .000 & 69.865 .547 .616 & $116,76 \%$ \\
\hline 2015 & 60.175 .555 .000 & & 60.175 .555 .000 & 47.472 .634 .467 & $78.88 \%$ \\
\hline 2016 & 63.175 .555 .000 & 10.000 .000 .000 & 53.175 .555 .000 & 29.307 .864 .329 & $54.59 \%$ \\
\hline 2017 & 75.182 .755 .000 & & 75.182 .755 .000 & 11.560 .110 .538 & $15,37 \%$ \\
\hline
\end{tabular}

Sumber: Dinas Penamaman Modal Pelayanan Terpadu Satu Pintu Kabupaten Karawang

Sumbangsi retribusi pelayanan perizinan tertentu yang diberikan masyarakat dalam Pendapatan Asli daerah (PAD) tidaklah setinggi tingkat pelayanan yang didapatkan oleh birokrat. Dalam hal penyediaan pelayanan perizinan, aparat birokrasi sering kali tidak memberikan kepastian waktu dalam pelayanan dan keterbukaan biaya 
pelayanan yang dibutuhkan. Pelaksanan pelayanan perizinan mendirikan bangunan di DPMPTSP Kabupaten Karawang dapat dikatakan belum berjalan sesuai dengan yang diharapkan masyarakat sebagai pengguna pelayanan. Dalam hal ini DPMPTSP sebagai penyedia pelayanan perizinan mendirikan bangunan birokrat memberikan pelayanan perizinan dengan proses yang lama, tidak ada kepastian waktu dalam pelayanan perizinan serta prosedur pelayanan perizinan tanpa kejelasan. Birokrasi dalam pelayanan perizinan mendirikan bangunan yang belum berjalan dengan baik didasarkan pada hasil survai indeks kepuasaan masyarakat atas penyelenggaran pelayanan perizinan yang diselenggarakan oleh DPMPTSP Kabupaten Karawang yang belum berjalan dengan baik.

Adapun pertanyaan penelitian yang diajukan adalah bagaimana karakter birokrasi dalam pelayanan perizinan mendirikan bangunan di DPMPTSP Kabupaten Karawang berdasarkan temuan menunjukan terdapat karakteristik utama birokrasi dalam pelayanan perizinan mendirikan bangunan di DPMPTSP Kabupaten Karawang hasil dari penelitian menunjukan karakter type ideal weberian dan Caiden yang terdiri dari, pertama, hirarkhi yang panjang, kedua, formalisasi prosedur aturan, ketiga, debirokratisasi.

\section{b. Prinsip hierarki wewenang (The Principle of Hierarchi) Birokrasi Pemerintah Dalam Pelayanan Perizinan Mendirikan Bangunan Di DPMPTSP Kabupaten Karawang}

Dalam hal ini birokrasi di DPMPTSP Kabupaten Karawang penyelenggaran pelayanan perizinan mendirikan bangunan terdapat tahapan yang panjang sampai dengan di terbitkannya izin mendirikan bangunan. Jika dilihat dari proses prosedur pelayanan yang diselenggarakan oleh DPMPTSP Kabupaten Karawang dalam pelayanan perizinan mendirikan bangunan ada tahap-tahap yang harus dilalui masyarakat sebagai pemohon, tahapan-tahapan tersebut sebagai cara yang digunakan oleh pimpinan DPMPTSP untuk memantau jalanya proses pelayanan pada masyarakat. Dalam tahaptahapan tersebut ada beberapa persyaratan yang wajib dilengakapi oleh pemohon dan ada prosedur yang harus dilalui dari pendaftaran sampai dengan diterbitkan atau dikeluarkan izin mendirikan bangunan tahapan ini yang bertanggung jawab pendaftaran pelayanan perizinan.

Sebelum masuk pada tahap pengurusan izin mendirikan bangunan, masyarakat sebagai pemohon wajib melengkapi semua persyaratan-persyaratan yang ditentukan yang berdasarkan pada peraturan daerah. Bagian pertama, pendaftaran pelayanan persyaratan yang harus disiapkan dalam proses pengurusan izin mendirikan bangunan merupakan hal yang wajib untuk dipenuhi. Persyaratan ini meliputi kelengkapan berkas administrasi dari pemohon serta persyaratan biaya retribusi yang dikenakan oleh DPMPTSP Kabupaten Karawang. Adapun persyaratan secara administrasi masyarakat 
sebagai permohonan surat izin mendirikan bangunan secara umum sebagaimana yang tertuang dalam Peraturan Daerah Kabupaten Karawang Nomor 22 Tahun 2016 Tentang penyelenggaran PTSP Di Kabupaten Karawang. Persyaratan berkas secara administrasi yang mesti dilengkapi oleh masyarakat sebagai pemohon surat izin mendirikan bangunan yaitu sebagai berikut:

a. Foto copy Karta Tanda Penduduk (KTP) pemohon yang berlaku

b. Foto copy surat bukti pemilikan atau penguasaan tanah

c. Foto copy lunas pajak bumi dan bangunan (PBB) tahun berjalan

d. Surat pernyataan tidak keberatan dari tetangga

e. Surat pernyataan pemohon bahwa lokasi atau tanah tidak dalam keadaan sengketa dan diketahui lurah dan camat setempat

f. Gambar rencana bangunan dan perhitungan konstruksi 5 (lima) rangkap dengan melampirkan surat izin perencaan bangunan (SIPB)

g. Pas foto ukuran $4 \times 4 \mathrm{~cm}$ sebanyak 2 lembar

Mekanisme persyaratan berkas secara administrasi prosedur dari mulai pendaftaran pelayanan di bagian pendaftaran yang diatur secara rinci dan detail bagi DPMPTSP Kabupaten Karawang untuk meningkatkan kualitas pelayanan sehingga dapat dijadikan sebagai kontrol proses pelaksaan pelayanan. Oleh karena itu, sistem hirarkhi dalam pelayanan perizinan yang dilaksanakan oleh DPMPTSP Kabupaten Karawang disesuaikan dengan alur mekanisme yang menjadi tugas birokrat yang diberikan untuk melakukan pelayanan perizinan kepada masyarakat. Mekanisme ini diatur dalam Peraturan Daerah Kabupaten Karawang Nomor 22 Tahun 2016 Tentang penyelenggaran PTSP Di Kabupaten Karawang. Berkaitan dengan peraturan daerah yang berhubungan dengan proses pelayanan perizinan sampai dengan penerbitan Izin mendirikan bangunan sekarang di selenggarakan oleh DPMTPSP Kabupaten Karawang.

Keberadaan hirarkhi yang panjang dalam birokrasi pelayanan perizinan tidak dapat dihindari dijadikan sebagai instrumen untuk mengerakan birokrasi agar terkoordinasi secara baik serta dapat memperjelas tanggungjawab dalam birokrasi. Tujuan dari hirarkhi dan prosedur dalam pelayanan perizinan mendirikan bangunan untuk memberikan penjelasan prosedur tahapan-tahapan yang mesti ditempuh oleh masyarakat sebagai pemohon izin mendirikan bangunan, selain itu untuk menyelaraskan keseluruhan bagian unit kerja hingga menjadi kesatuan proses yang efisien dan efektif dalam memberikan informasi kepada masyarakat.

Keberadaan hirakhi yang panjang dalam memberikan pelayanan perizinan mendirikan bangunan di DPMTPSP Kabupaten Karawang terdapat makna yang sama seperti yang di kemukakan oleh max weber dalam type birokrasi idealnya. Sebagai ciri khas birokrasi weber yaitu hirarkhi yang panjang, hirarkhi membantu pimpinan birokrasi untuk melakukan supervisi dan kontrol terhadap para anggotanya, tanpa adanya hirarkhi 
maka sulit bagi pimpinan birokrasi dapat melakukan koordinasi dengan baik sehingga semua kegiatan organisasi dapat berjalan secara sinergis.

Max weber menyatakan bahwa suatu struktur organisasi yang tersusun secara hierarkis (berjenjang), di mana setiap jenjang sudah ditetapkan bidang tugasnya masing-masing. Setiap jenjang adalah bagian dari sistem organisasi secara keseluruhan, yang diisi oleh pejabat-pejabat dengan tugas dan fungsi masing-masing yang dapat dipisahkan secara jelas antara tugas pejabat yang satu dengan pejabat yang lain. Namun demikian, tanggung jawab akhir berada pada pimpinan puncak organisasi tersebut.

Yang dimaksud dengan prinsip hirarkhi yang panjang karakter birokrasi weberian pada konteks ini dapat diartikan sebagaimana petugas yang lebih rendah akan tunduk kepada pejabat yang lebih tinggi sehingga akan mempermudah pembinaan dan pengawasan pekerjaan di Kantor DPMPTSP Kabupaten Karawang memberikan pelayanan sesuai dengan waktu yang diharapkan oleh masyarakat serta sesuai ketentuan waktu maksimal pelayanan yang sudah ditetapkan oleh DPMTPSP Kabupaten Karawang. Karena hal tersebut berdampak pada kepercayaan masyarakat kepada pemerintah sebagai penyelengaran pelayanan perizinan.

Dengan demikian, menurut perpektif penulis menyatakan bahwa hirarkhi yang panjang menciptakan distorsi komunikasi dan informasi dalam memberikan pelayanan perizinan untuk mendirikan bangunan melalui jenjang hirarkhi yang panjang cenderung melakukan reinterprestasi sesuai dengan pengetahuan yang dimiliki oleh birokrat dan kepentingan dari masing-masing dalam hirarkhi tersebut. Semakin panjang hirarkhi dalam pelayanan perizinan dari suatu birokrasi semakin besar kecenderungan terjadinya distorsi dalam komunikasi memberikan informasi kepada masyarakat sebagai pemohon pelayanan.

Dengan demikian, dapat ditarik kesimpulan menurut perspektif penulis bahwa hirarkhi yang panjang dalam tahapan pelayanan perizinan mendirikan bangunan yang disediakan oleh DPMTPSP Kabupaten Karawang belum berjalan dengan baik masih terdapat kurang konsistensi dalam pelayanan perizinan mendirikan bangunan kepada masyarakat sebagai pengguna jasa pelayanan. Bahwa stuktur yang hirarkhi yang berjenjang cenderung tidak efisien secara organisator karena terdapat mata rantai yang mesti dilalui dalam pengambilan keputusan akan berpotensi menimbulkan disorientasi birokrasi dalam memberikan pelayanan perizinan. Hirarkhi yang panjang juga berdampak pada pelayanan yang dirasakan oleh masyarakat sebagai pengguna jasa. Birokrasi yang semestinya berorientasi pada masyarakat dalam memberikan pelayanan tapi para birokrat ketergantungan pada hirarkhi yang panjang hal ini menyebabkan orientasi birokrat bukan terfokus pada pelayanan pada masyarakat melainkan kepada atasan nya. 


\section{c. Formalisasi Aturan Dan Prosedur Birokrasi Pemerintah Dalam Pelayanan Perizinan Mendirikan Bangunan Di DPMPTSP Kabupaten Karawang}

DPMPTSP Kabupaten Karawang telah diberi kewenangan untuk melaksanakan pelayanan administrasi perizinan sesuai dengan Peraturan Daerah Kabupaten Karawang Nomor 22 Tahun 2016 Tentang Penyelenggaran Pelayanan Terpadu Satu Pintu Kabupaten Karawang. DPMPTSP Kabupaten Karawang merupakan salah satu perangkat pemerintah daerah yang menerapkan sistem pelayanan satu pintu. DPMPTSP Kabupaten Karawang seabgai instansi yang khusus bertugas memberikan pelayanan administrasi mengenai perizinan yang langsung berinteraksi kepada masyarakat. Sebagai terobosan baru atau inovasi manajemen pemerintah daerah yang diharapkan mampu memberikan pelayanan publik yang berkualitas sesuai dengan tuntutan dan harapan masyarakat.

Penyelenggaran pelayanan terpadu satu pintu telah diatur dalam pelaksanaanya sesuai dengan peraturan daerah yang berlaku. Pelaksanaan pelayanan perizinan kepada masyarakat mempunyai keleluasaan mengenai apa yang harus dikerjakan sesuai dengan regulasi yang telah ditetapkan, siapapun yang melaskanakan pekerjaan pelayanan kepada masyarakat mesti sesuai dengan aturan yang telah ditetapkan dan sebaliknya juga masyarakat sebagai pengguna jasa pelayanan atas pelayanan yang diselenggarakan oleh DPMPTSP Kabupaten Karawang harus diikuti sesuai dengan regulasi. Legalitas hukum pelayanan perizinan terpadu satu pintu yang telah diatur dalam beberapa peraturan daerah seabgai berikut ini:

a. Undang-Undang Nomor 25 Tahun 2007 Tentang Penanaman Modal

b. Peraturan Daerah Kabupaten Karawang Nomor 2 Tahun 2015 Tentang Penanaman Modal

c. Peraturan Daerah Kabupaten Karawang Nomor 2 Tahun 2016 Tentang Izin Lokasi

d. Peraturan Daerah Kabupaten Karawang Nomor 7 Tahun 2016 Tentang Retribusi Pelayanan Perizinan

e. Peraturan Daerah Kabupaten Karawang Nomor 14 Tahun 2016

f. Tentang Pembentukan dan Susunan Perangkat Daerah Kabupaten Karawang

g. Peraturan Daerah Kabupaten Karawang Nomor 22 Tahun 2016 Tentang Penyelenggaran Pelayanan Terpadu Satu Pintu Kabupaten Karawang

h. Peraturan Bupati Karawang Nomor 68 Tahun 2015 Tentang Perubahan Ketiga Atas Perbup No. 40 Tahun 2014 tentang Pelimpahan Sebagian Urusan Pemerintah dari Bupati Karawang kepada Perangkat Daerah Kabupaten Karawang; 
270 | Rachmat Ramdani. Karakter Birokrasi Pemerintahan...

i. Peraturan Daerah Kabupaten Karawang Nomor 8 Tahun 2015 Tentang Bangunan Gedung

DPMPTSP Kabupaten Karawang dalam memberikan atau melayani perizinan khususnya mendirikan bangunan selalu mengacu pada dasar hukum atau regulasi yang telah ditetapkan. Formalisasi aturan dan prosedur dalam birokrasi pelayanan perizinan mendirikan bangunan yang diselenggarakan oleh DPMPTSP Kabupaten Karawang, sebagai mencerminkan birokrasi type ideal birokrasi weberian yang menyatakan bahwa formalisasi diperlukan sebagai dasar bagi pengambilan keputusan seorang pejabat birokrasi dalam memberikan pelayanan agar pelayanan yang diberikan dapat cepat dan adil.

Tentu sulit bagi birokrasi untuk dapat memberikan pelayanan yang cepat dan adil tanpa ada prosedur dan aturan yang jelas mengaturnya. Jika seorang birokrasi harus menilai dan memutuskan sendiri tanpa adanya prosedur dan aturan yang dapat mempermudah dan membantunya setiap menghadapi masyarakat yang membutuhkan pelayanan maka pelayanan birokrasi akan sangat bertele-tele dan mungkin juga berbeda-beda antar masyarakat. Birokrasi weberian mengajarkan bahwa formalisasi untuk memastikan adanya standar pelayanan, weber juga mengajarkan agar setiap masyarakat yang datang sebagai kasus sehingga masyarakat yang berhubungan dengan birokrasi seperti kasus sama akan memperoleh perlakuan yang sama. Max weber menyatakan bahwa anggota organisasi mentaati proses jabatan hanyalah dalam kapisitasnya sebagai anggota organisasi dan yang dipatuhinya semata-mata adalah hukum. Secara pribadi birokrat adalah person yang bebas, ia tunduk pada otoritas hanya berkenaan dengan kewajiban-kewajiban impersonal dari jabatannya. Ketaatan ditujukan bukan kepada individu pejabatnya, tetapi semata-mata kepada perintahnya yang berdasarkan hukum sehingga membentuk tatanan impersonal.

Dalam perspektif penulis, pemberian pelayanan perizinan oleh aparat birokrat masih tetap cenderung memprioritaskan peraturan dari pada kepentingan masyarakat sebagai pemohon pelayanan. Masih kuatnya kecenderungan birokrasi dalam pelayanan perizinan di DPMPTSP terlihat dari penjelasan-penjelasan diatas dalam menjalankan tugasnya pada peraturan perundang-undangan dan peraturan daerah sebagai pedoman utama. Kepentingan masyarakat sebagai pengguna jasa dari pelayanan yang diselenggarakan oleh birokrasi dalam pelayanan akan kebutuhan pelayanan yang cepat, terbuka dan adanya kepastian tidak pernah menjadi acuan dalam pemberian pelayanan oleh birokrasi.

Penulis memberikan pandangan bahwa transpransi informasi birokrasi dalam pelayanan menjadi isu yang penting bagi untuk melakukan perbaikan dari kinerja birokrasi pemerintahan. Dengan adanya transpransi informasi birokrasi dalam pelayanan 
perizinan dapat memberikan implikasi pada penurunnya tingkat korupsi para birokrat yang memburu para rente mencari proyek-proyek perizinan dalam birokrasi pelayanan publik. Selain itu, untuk memperbaiki kinerja birokrasi dalam pelayanan dengan mengacu pada kepuasaan publik sebagai pengguna jasa dengan pelayanan yang akuntabel.

\section{d. Debirokratisasi Birokrasi Pemerintah Dalam Pelayanan Perizinan Mendirikan Bangunan Di DPMPTSP Kabupaten Karawang}

Dalam kaitan dengan pelayanan perizinan Mendirikan bangunan di Kabupaten Karawang, BPMPT secara khusus melakukan penyederhanakan pelayanan publik adanya pemangkasan struktur dan prosedur dalam proses penyelenggaran pelayanan perizinan dengan tujuan untuk menggatasi permasalahan pelayanan. Tujuan pemangkasan birokrasi menjadi DPMPTSP Kabupaten Karawang dalam pelaksanaan tugas dan fungsinya tentu memilki pengaruh terhadap upaya pembangunan penanaman modal serta perkembangan perbaikan pelayanan publik di Kabupaten Karawang, khususnya dalam penyelenggaraan perizinan mulai dari tahap sampai tahap terbitnya dokumen dilakukan dalam satu tempat. Pemerintah Daearah Kabupaten Karawang mempunyai komitmen untuk memangkas birokratisasi dengan membentuk kelembagaan pelayanan perizinan untuk menjadi leading sector dalam semua pelayanan perizinan.

DPMPTSP diberikan kewenangan untuk melaksana pelaksanaan teknis untuk pelayanan perizinan mendirikan bangunan dengan sistem prosedur pelayanan perizinan secara integrative yang tidak hanya bersifat parsial atau hanya administrative semata. Dimana pelayanan perizinan untuk mendirikan bangunan yang dilayani secara tunggal oleh DPMPTSP Kabupaten Karawang tidak perlu melakukan koordinasi dengan Dinas teknis lainnya, melainkan pelayanan perizinan dengan pengurusan satu pintu. Melakukan debirokratisasi kelembagaan dari BPMPT menjadi DPMPTSP yang berdasarkan pada Peraturan Presiden Nomor 18 Tahun 2016 Tentang Perubahan STOK. Kabupaten Karawang banyak mengalami perombakan kelembaggan salah satunya DPMPTSP. Pemerintah Daerah Kabupaten Karawang melakukan debirokratisasi kelembaggan pelayanan perizinan menjadi DPMPTSP Kabupaten Karawang yang diberikan kewenangan penuh tugas dan fungsi untuk menyelenggarakan pelayanan perizinan khusunya untuk pelayanan perizinan mendirikan bangunan.

Terdapat makna yang sama hal harus dilakukan oleh pemerintah dalam melakukan strategi reformasi birokrasi yang di kemukakan oleh Caiden. Caiden yang menolak model birokrasi weberian menganjurkan debirokratisasi sebagai strategi reformasi birokrasi. Menurut Caiden debirokratisasi merupakan memangkas struktur dan prosedur birokrasi yang berbelit-belit untuk efisiensi dan efektivitas kepemerintahan. Debirokratisasi hanya perlu dilakukan ketika birokratisasi sudah berlebihan dan melewati titik optimalisasinya. 
272 | Rachmat Ramdani. Karakter Birokrasi Pemerintahan...

Menurut perspektif penulis, mengenai debirokratisasi menyangkut pembenahan kewenangan yang dimiliki oleh DPMPTSP Kabupaten Karawang yang berkaitan dengan pelayanan perizinan mendirikan bangunan adanya kajian teknis, selain itu melakukan perombakan struktural dengan penambahan satuan kerja untuk bidang teknis pelayanan perizinan. Satuan kerja dengan penambahan kewenangan yang dimilki oleh DPMPTSP dimaksudkan untuk tujuan penyelenggaran pelayanan perizinan yang lebih efektif dan efisien.

Dengan demikian, debirokratisasi kelembagaan dari DPMPTSP Kabupaten Karawang berjalan dengan baik sebagai upaya perbaikan pelayanan perizinan kepada masyarakat. Tujuan dari debirokratisasi memangkas birokratisasi untuk menata ulang tugas dan fungsi serta kewenangan yang mesti dimiliki oleh DPMPTSP sebagai Dinas yang menyelenggarakan pelayanan perizinan. Kebijakan debirokratisasi tersebut memutuskan mata rantai birokrasi dalam prsedur pelayanan perizinan yang panjang setelah reorganisasi kelembagaan menjadi DPMPTSP Kabupaten Karawang sebagai penyelenggaran pelayanan perizinan terpadu.

\section{Kesimpulan Dan Saran}

\section{a. Kesimpulan}

Berdasarkan hasil pembahasan maka dapat disimpulkan bahwa karakter birokrasi pemerintahan dalam pelayanan perizinan mendirikan bangunan di DPMPTSP Kabupaten Karawang terdapat karakter birokrasi type ideal yang dikemukakan oleh Weberian dan Caiden. Karakter birokrasi pemerintahan di DPMPTSP Kabupaten Karawang. Pertama, Keberadaan hirakhi yang panjang dalam memberikan pelayanan perizinan mendirikan bangunan di DPMTPSP Kabupaten Karawang terdapat makna yang sama seperti yang di kemukakan oleh max weber dalam type birokrasi idealnya. Kedua, Formalisasi aturan dan prosedur dalam birokrasi pelayanan perizinan mendirikan bangunan yang diselenggarakan oleh DPMPTSP Kabupaten Karawang, sebagai mencerminkan birokrasi type ideal birokrasi weberian yang menyatakan bahwa formalisasi diperlukan sebagai dasar bagi pengambilan keputusan seorang pejabat birokrasi dalam memberikan pelayanan agar pelayanan yang diberikan dapat cepat dan adil. Ketiga, debirokratisasi merupakan memangkas struktur dan prosedur birokrasi yang berbelit-belit untuk efisiensi dan efektivitas kepemerintahan. Debirokratisasi hanya perlu dilakukan ketika birokratisasi sudah berlebihan dan melewati titik optimalisasinya.

\section{b. Saran}

Berdasarkan hasil pembahasan dan kesimpulan diatas maka saran yang dapat penulis berikan kepada DPMPTSP pelayanan perizinan IMB Kabupaten Karawang dapat berjalan dengan baik adalah sebagai berikut: 
Pertama, hirarkhi yang panjang dalam pelayanan perizinan IMB di DPMPTSP memiliki potensi serangkaian masalah birokrasi yang besar tidak akan efektif dan efisien serta hirarkhi yang ketat tidaka akan relevan di era digital, maka penulis sarankan perlu mengembangkan pelayanan perizinan menggunakan pendekatan teknologi informasi dan komunikasi.

Kedua, Formalisasi aturan dan prosedur sebagai dasar dalam pengambilan keputusan pimpinan dalam memberikan pelayanan agar pelayanan yang diberikan cepat dan adil, maka perlu memperbaiki pola birokrasi dalam pelayanan perizinan IMB yang transparansi informasi dan akuntabel yang mengacu pada kepuasan publik sebagai pengguna jasa.

Ketiga, Debirokratisasi di DPMPTSP Kabupaten Karawang perlu adanya penataan yang komprehensif dari mulai sumber daya manusia pelaksana pelayanan perizinan DPMPTSP Kabupaten Karawang kedepan sebagai institusi pelayanan perizinan yang ramah dan prosedur pelayanan yang jelas serta berkualitas tinggi.

\section{DAFTAR PUSTAKA}

Caiden, Gerald E. (1991) Administrative Reforms Comes Of Ages. New York: Walter The Gruyter

Denhardt, J.V. \& Denhardt, R.B. (2003) The New Public Service: Serving, NotSteering. NewYork: M.E.Sharpe.

Eep Saefulloh Fatah. (1998). Catatan Atas Gagalnya Politik Orde Baru.Yogyakarta: Pustaka Pelajar.

Kristiadi. J.B. (1991) Peran aparatur Pemerintah Dalam Era Pembangunan. Bandung: Sesimpol Lembang.

Miftah, Thoha. (2008) Perilaku Organisasi Konsep Dan Aplikasinya. Jakarta:PT. Raja Grapindo

Miles, M.B \& huberman, A.M. (1992) Analisa data kualitaif. (penerjemah: Rohid, R.T). UI Press. Jakarta

Ridwan, Juniarso \& Sudrajat Sodik. (2009) Hukum Administrasi Negara Dan Kebijakan Pelayanan Publik. Bandung: Nuansa.

Ryaas Rasyid, (1997) Birokrasi Pemerintahan Politik Orde Baru.Jakarta: Yasrif Watampone.

Weber, Max. (1947) The Theory of Social and Economic Organization. Diterjemahkan oleh A.M. Henderson dan Talcott Parsons. New York USA: Oxford University Press.

\section{Peraturan Perundang-undangan}

Peraturan Presiden Nomor 27 Tahun 2009 Tentang Pelayanan Terpadu Satu Pintu Bidang Penanaman Modal.

Peraturan menteri dalam neggri nomor 24 tahun 2006 Tentang Pedoman Penyelenggaran Pelayanan Terpadu Satu Pintu 
274 | Rachmat Ramdani. Karakter Birokrasi Pemerintahan...

Peraturan Daerah Nomor 17 Tahun 2012 Tentang Penyelenggaraan Pelayanan Perizinan Terpadu

Peraturan Bupati Karawang Nomor 40 Tahun 2011 Tentang Pelimpahan Sebagian Urusan Pemerintahan dari Bupati Karawang kepada Perangkat Daerah Kabupaten Karawang 